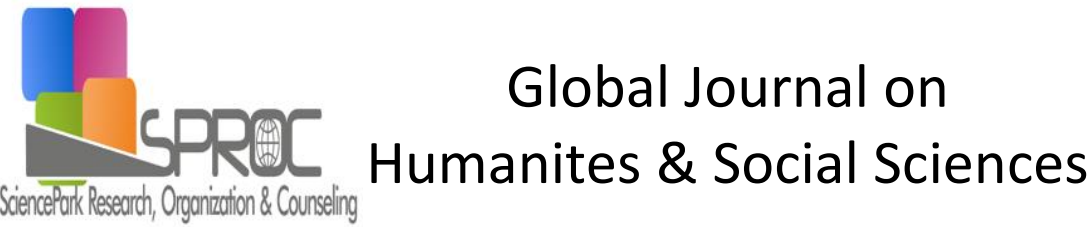

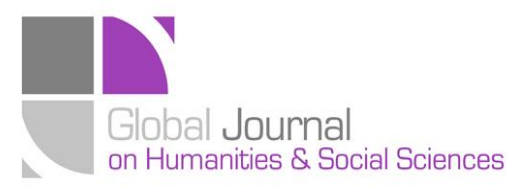

Issue 3 (2016) 648-656

Selected Paper of 4th World Conference on Design and Arts, (DAE-2015)

26-28 June 2015, St.Petersburg Christan University, St. Petersburg, Russia.

\section{An overview of classical ottoman art of fabric}

Nurhan Ozkan *, Selcuk University, Fashion Design Department, Konya 42075, Turkey.

\section{Suggested Citation:}

Ozkan, N. (2016). An overview of classical ottoman art of fabric, Global Journal on Humanites \& Social Sciences. [Online]. 03, pp 648-656. Available from: http://sproc.org/ojs/index.php/pntsbs doi: http://dx.doi.org/10.18844/gjhss.v0i0.269

Received January 01, 2015; revised March 15, 2015; accepted April 23, 2015.

Selection and peer review under responsibility of Prof. Dr. Milan Matijevic.

(C2016 SciencePark Research, Organization \& Counseling. All rights reserved.

\begin{abstract}
Seljuk Turks who began to settle in Anatolia since 11th century showed a great improvement in this area by combining the weaving tradition that they carried from Central Asia, Transoxiana, Khwarezm and Iran with the savings in Anatolia (Ülgen, 1996). Turkish fabrics began to get their most characteristic motifs and a thin and a perfect weaving technique just to the end of 15th century. Reaching its highest level in 16thcentury, our fabric weaving technique improved after such a long development cycle (Süslü, 1976).

All the arts had their golden age during the classical Ottoman Period. It is also the most magnificent age for 16th century Turkish fabric art. It has been effective in the selection of topic that fabrics wear out in time and design schemas on them face the danger of evanescence because of their raw materials.

In this research, relevant resources have been searched and fabric figure drawings were drawn by taking photos from the museums that have classical Ottoman Period fabrics. The weaving centers, raw materials, colors and figures of classical Ottoman Period fabrics have been established and has set out the importance of the Classical Ottoman fabric art.
\end{abstract}

Keywords: Fabric, Art, Classical Period

* ADDRESS FOR CORRESPONDENCE: Nurhan Ozkan, Selcuk University, Fashion Design Department, Konya 42075, Turkey. E-mail address: nozkan@selcuk.edu.tr / Tel.: +90 332 2231766; fax: +90 3322412862. 
Ozkan, N. (2016). An overview of classical ottoman art of fabric, Global Journal on Humanites \& Social Sciences. [Online]. 03, pp 648-656. Available from: http://sproc.org/ojs/index.php/pntsbs doi: http://dx.doi.org/10.18844/gjhss.v0i0.269

\section{Introduction}

Fabric weaving is one of the oldest arts that has appeared according the results of people related with protecting of body, clothing or dressing according seasons (Özen, 1980). Seljuk Turks who has settled in Anatolia since the beginning of eleventh century, has shown a big achievement in this area by connecting the weaving tradition with Iran, Maveraunnehir and Khwarezm of course thanks to accumulations of Anatolia. It has been known that cotton and woolen fabrics gained fame in weaving centers that were available during Seljuk period (Ülgen, 1996).

The fabrics that have come from Anotolian Seljuk to our age are little but they can show the superiority of fabric art related with that period. There are lots of documentaries that can show the beauty of Seljuk's fabrics. Pilgrims can mention good things about Seljuk's fabrics. There is information about gold wire woven silk fabrics, and they had been sent to other statesmen and rich people in society by Sultans of Seljuk of courser as a gift (Önder, 1993).

\subsection{Development of Fabric Art in Ottoman Empire During Classical Period}

Anatolia Seljuk's fabrics explain the foundation of fabric art in Ottoman Empire. Thanks to a good quality of weaving and composition, Ottoman Empire has continued the fabric arts that have been created in Seljuk's country and so on. Drapery in Ottoman Empire improved with the conquest of İstanbul. Fatih Sultan Mehmet provided the continuation of local weaving by giving permission to people of istanbul staying at the same place, of course, after he had conquered istanbul. Turkish fabrics started to take their characteristic motifs, subtle and perfect weaving technique in the end of fifteenth century (Süslü, 1976). Bursa is a very important center in terms of velvet fabric weaving in fifteenth century. 100 parts of fabrics have been given to Prince Mustafa by woven fabrics in 1421. Gold, silver and fabric have been sent to King German and King Hungary as a gift in 1421 (Öz, 1946). The fabric art have been improved by the control of the palace after istanbul became capital. The fabric art has given its most beautiful examples as in other arts in sixteenth and seventeenth centuries.

Magnificent Sultan Suleyman used to like stylish and flashy clothes in contrast to Yavuz Sultan Selim's dressings. At the time of Magnificent Sultan Suleyman, Busbekq who explained the ceremonial gateaway of entourage procession in his letter said "The clothes of cavalries with gold and silver brocade attires shine brightly and the clothes which made of silk and satin are dark green, red or purple" (Uğurlu, 1994). He wrote all these things in his letters and showed that The Sultans had a good pleasure of dressing, they knew the fabrics well and all of them showed the wealthy of that time.

Identity and design racing have continued among other art areas related with Ottoman fabric art in sixteenth century. Shah Kulu, someone who is responsible for per miniaturists, applied "reed road" and all the identities of these things have been created in the time of Magnificent Sultan Suleiman. The types of identities were called "reed road" at that time. Per miniaturists (person who sews well Kara Memi participated the design race with the natural flowers. (not real resembles) in the middle of century. The fabric design has reached the quality to compete with the tile decoration during the process of fabric design. Moon, star, peacock, feather and small number of animal figures participated the creativity race that have been applied on tulips, hyacinths, carnations, roses and rosebuds, pomegranate, grenadine, pine cones and even apple tree. The changes of fabric patterns and traditional weaving improved and went on thanks to Ehl-i Hiref Organization (Küçükerman, 2007). This period has reached its peak in terms of fabric art and the beauty of patterns in both quality and best workers. The real gold and silver has increased the value of wire fabric one more (Tezcan, 2000). The most beautiful samples of fabrics belong to sixteenth century and artist gave their most important Works in this period (Dinçol, vd., 1982; Süslü, 1972; Züber, 1972; Nutku, 1985). 
When observed the book of Ehl-i Hiref in sixteenth century, aba, kemha and fabric weavers are exactly 27 people in 1525. In 1545, Kemha 75, aba 15, velvets 15 and they are together 105 people. But in 1557, 17 fabric weavers, 78 of Kemha, 18 velvets, 16 Kemha embroiderers and 16 Aba together, they are 146 people exactly who are art designers. Besides, there are 40-50 people miniaturists groups with them. The models which have been drawn and painted by these groups, than have been weaved by Kemha and velvets. It has been understood by the reports that these art designers were so good and valuable in terms of good weaving $(O ̈ z, 1946)$.

The number of silk weaving benches have been increased as 318 in the period of Magnificent Sultan Suleyman. The announcement is published because the changes of using the amount of silver and gold with silk fabrics have been realized. There has been fraud on plug and twists and it has been seen. In the announcement it has been stated that 100 of fabric weavers are good workers and ok, the others wouldn't let work, and at least they should pay 35 gold to work on, the fabrics would be checked and stamped and the fabrics without stamped wouldn't be sold (Yatman, 1945). So, the amount of gold and silver in fabrics and the quality of fabric have been controlled.

The people who were good with painting worked on only one colour because it has been used less colours on the fabrics of palace in classical period. There are markets called red and green painters. Bursa, Edirne and Istanbul are the most important cities in terms of paint industry. According the historical documents, the caravans with silk and fabrics have come to Bursa from abroad to be painted here. Red is the most used and important colour in Turkish fabrics. After red, the other ordinary colours are blue, green, black, white, beige, gold colour, dark Brown called "Surman". Contrast colours create good compositions while combining different colours. For example, contrast colours are heavy (dark) in surface of Kemha related with fabrics. A lot of colours have been used to embellish the fabric in different styles. Three colours most have been used in declamations (Sezgin, Önlü, 1994).

There are kemha, brocade, velvet, seraser, satin, taffeta, taffeta, travel, sofa, crepe, brocade, kutnu, aba in classical fabrics. In this study, Kemha and declamation have been placed. Kemha is especially used in making caftan. Its warp and weft are silk, the added wefts are made of silk or silver claps. Declamation is the only fabric that suits upholstery as used in clothing. It is a king of velvet in terms of touching technique. Generally, the surface is velvet, fabric with silver plugs or just opposite. It has been weaved like this explanation. Bursa is mostly famous for its velvet, çatma, declamation but İstanbul has been known as kemha and seraser fabrics since the second half of sixteenth century (Bilgi, 2007).

\section{The Classical Period Fabric Samples}

Nine samples from fabrics have been chosen that will reflect the classical period. Motif draws have been done for the fabrics chosen and colour motif and composition specialties are given below.

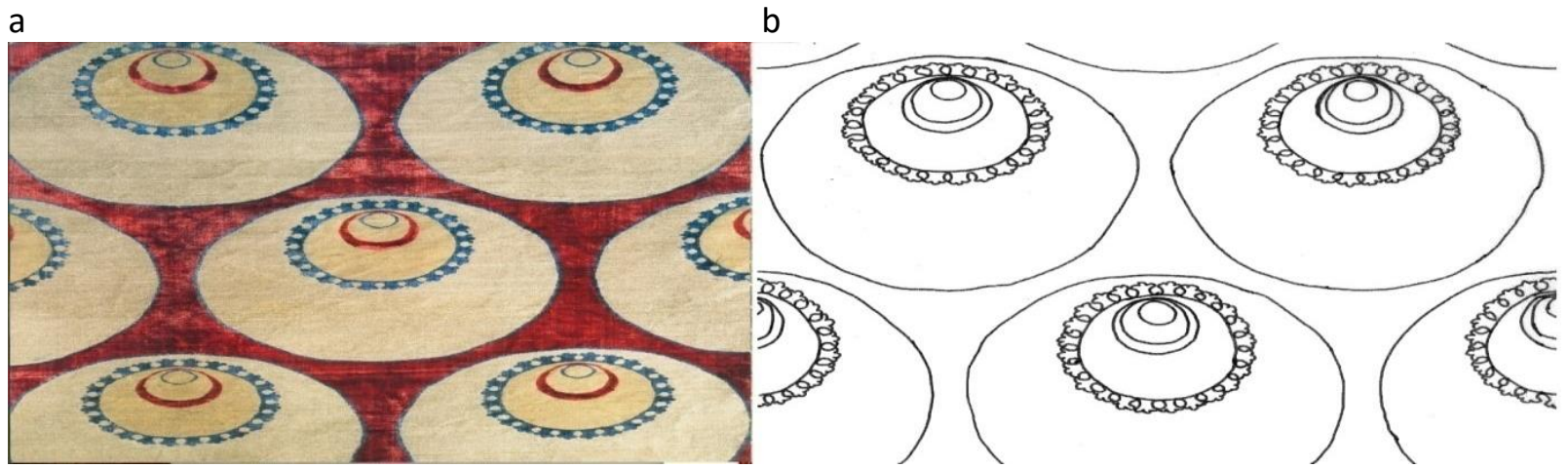

Fig. 1.(a)Çatma Fabrics with Locket (Bakırcı, 2012); (b)Drawing of Çatma Fabrics with Locket 
It is dated to sixteenth century. The cream lockets have been placed into the red surface (ground). The inside of lockets, there are five circles connected each other. The side by side palmets have been seen in fourth circle and blue line. Red, gold colour, cream and blue colours have been used in the declamation fabrics. The pattern composition has been seen that had been formed in staggered layout. The declamation fabrics are available in Mevlana Museum as the number of 616.

a

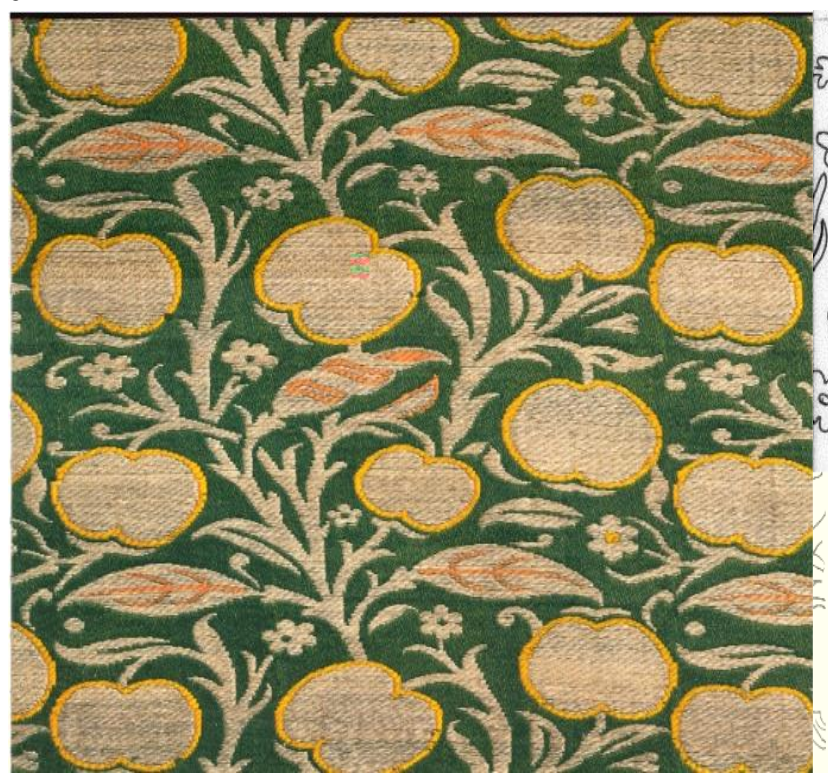

b

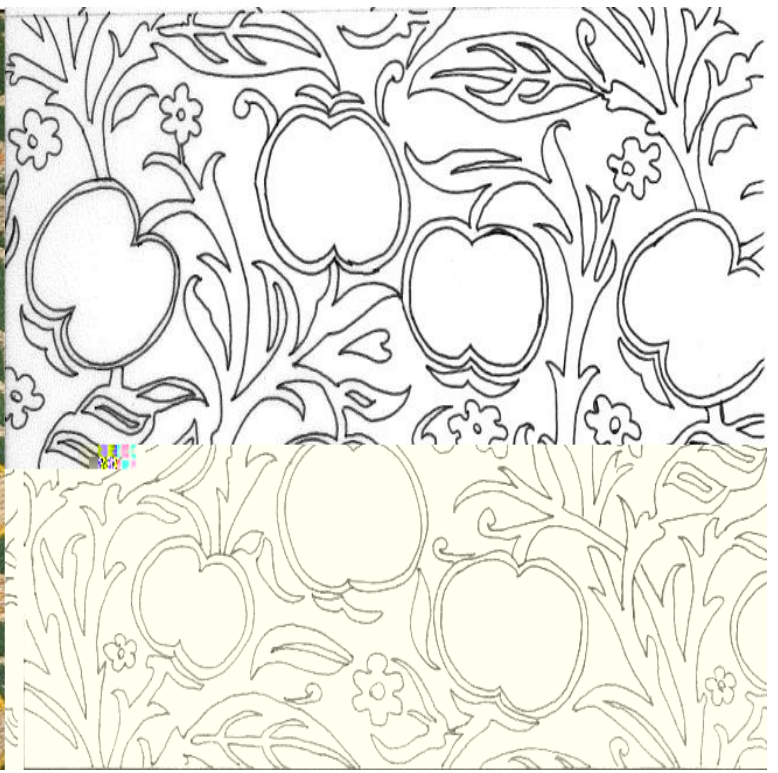

Fig. 2.(a) Kemha Fabric with Apple Motif ( Atasoy, 2001); (b)Drawing of Apple Motif Kemha Fabric

It is dated to sixteenth century. It has been used as a short-sleeved robe. The cream coloured apples, leaves, branches, flowers compositions are seen on the green coloured surface. The surroundings of apples have been contoured by gold colour. The vessels of leaves have been emphasized by orange colour. Green, cream colour, gold colour, orange colours have been seen. The pattern tabele have been seen that had been placed in scroll up order. Caftan that had been created by Kemha's fabric can be seen in Topkapı Museum as the number of 13/176.

a

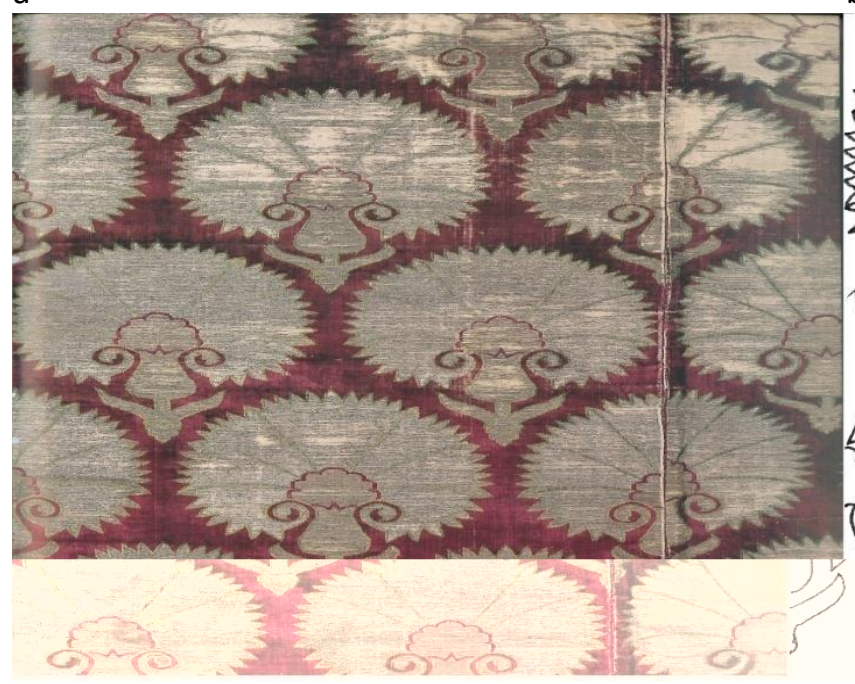

b

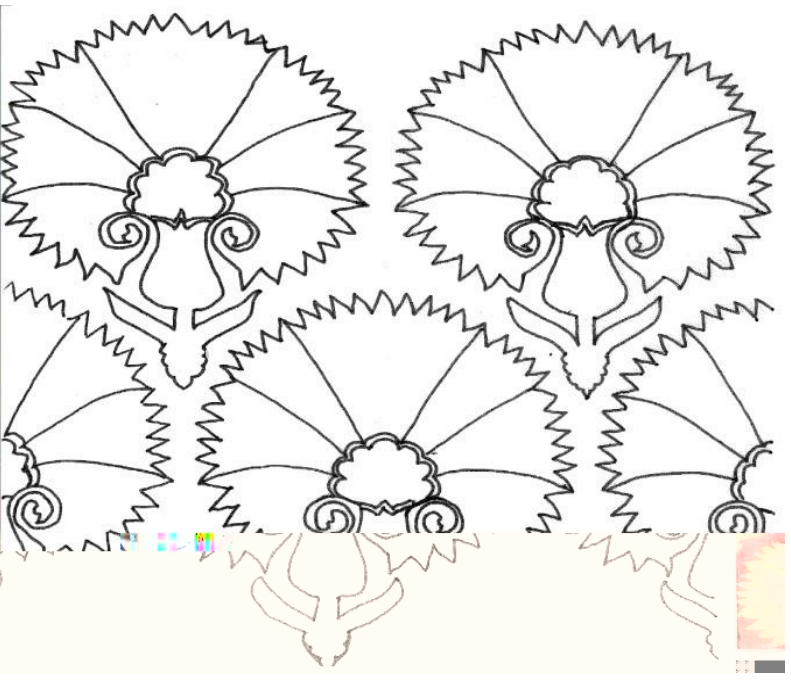

Fig. 3.(a)Çatma Fabric with Clove ( Bakırcı, 2012); (b)Drawing of Çatma Fabric with Clove 
It is dated to seventeenth century. Stylized cloves filled the red fabric surface. Seven parts of clove motifs have been placed on to the handle and leafy tulips. Red, cream, green colours have been seen. Pattern placement has been made in staggered layout. Declamation fabric is available in Mevlana Museum as the number of 600 .

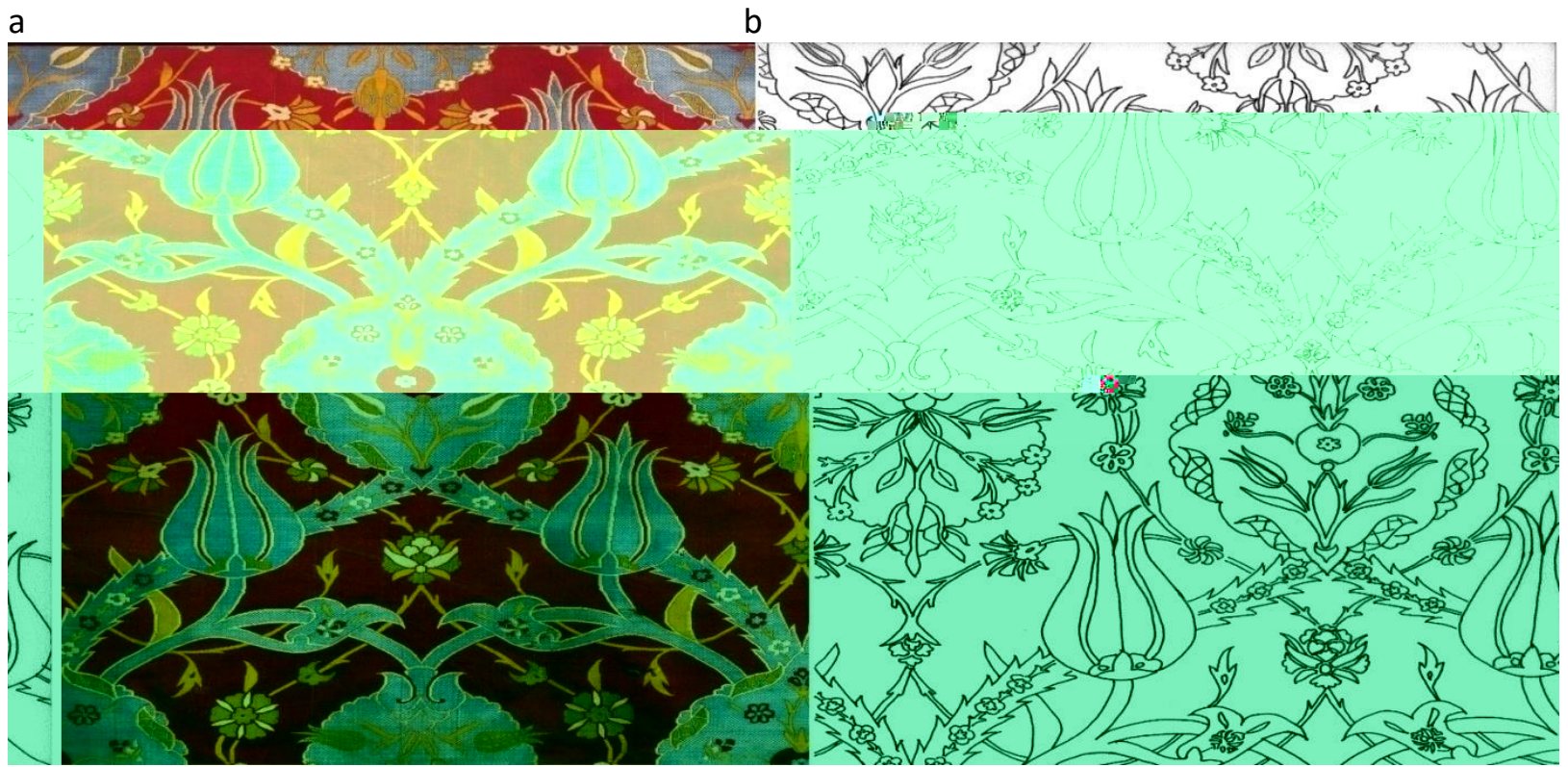

Fig. 4.(a)Kemha Fabric with Tulip Motif ( Atasoy, 2001); (b)Drawing of Kemha Fabric with Tulip Motif

It is dated to the quarter of sixteenth century. It has been used as a long-sleeved caftan. Blue tulips, rumil branches, medallions formed with on to the red surface stand out as a whole. Rosebud and leaves that comes more for medallion, also handle moves from the palmet fill the inside of medallion that include palmet other sides, the tulips fill the same place as well. Pomegranate motif in the middle of the second medallion, tulips motifs have been seen near pomegranate together. The compositions have been created by Hataies, claws, verbena, and the curved branches. Red, blue, gold colour, green and cream colours have been used. Fabric compositions have been created in horizontal layout scheme. The caftan that was made of Serenk fabric is available in Topkapı Museum as the number of $13 / 932$.

a

b

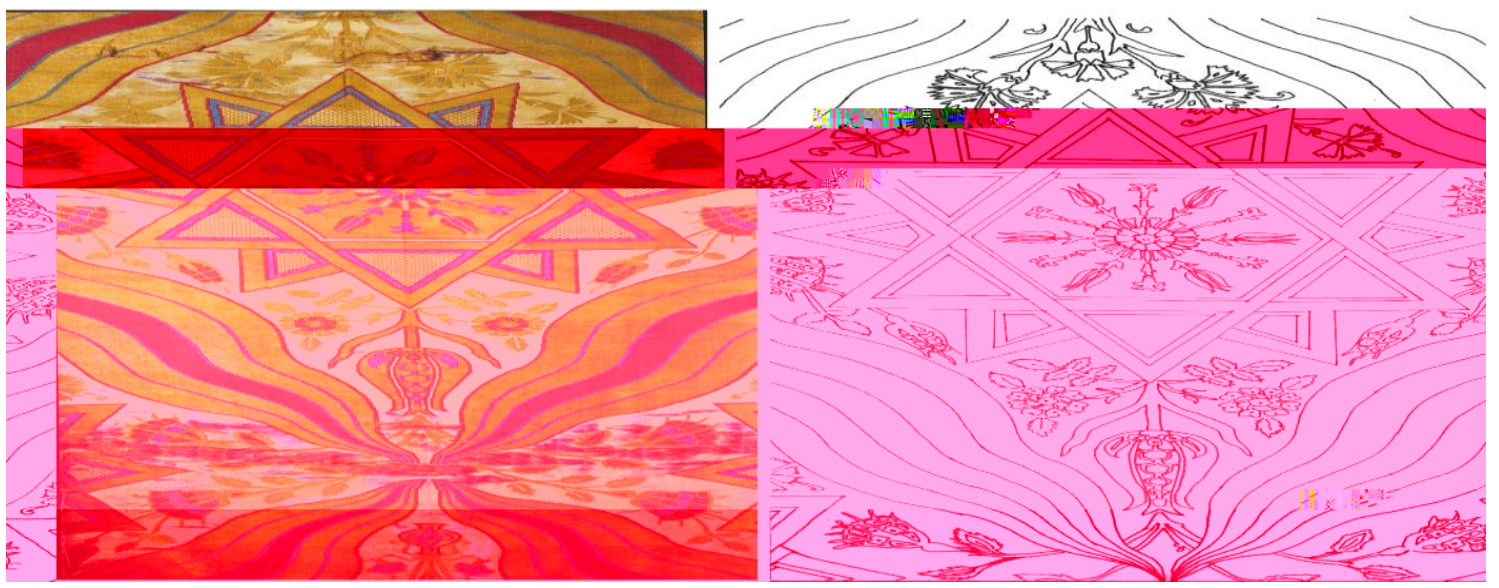

Fig. 5. (a)Kemha Fabric with the Seal of Suleyman(Atasoy, 2001); (b) Drawing of Kemha Fabric with the Seal of Suleyman 
It is dated to the third quarter of the sixteenth century. It has been used as short-sleeved caftan. Cream colour is on the surface and there is Suleyman motif that comes to eyes at first. It has been seen tulip and hyacinth motif in the seal of Suleyman. Carnations from the bottom of the vase, a coming out of the roses at the top of tulips, roses bud in the side have been seen well. Tiger skin motif has surrounded the sides of the seal of Suleyman. Cream, gold colour, red and blue colours have been seen. The pattern composition has been created in the staggered layout. The caftan that was made of Kemha fabric is available in Topkapı Museum as the number of 13/21.

a

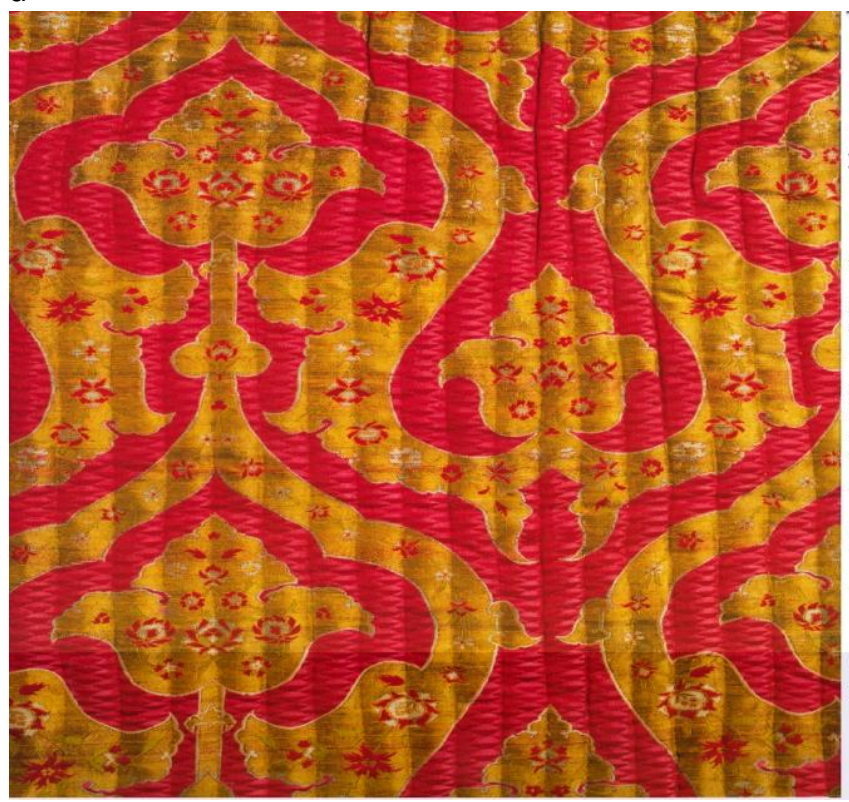

b

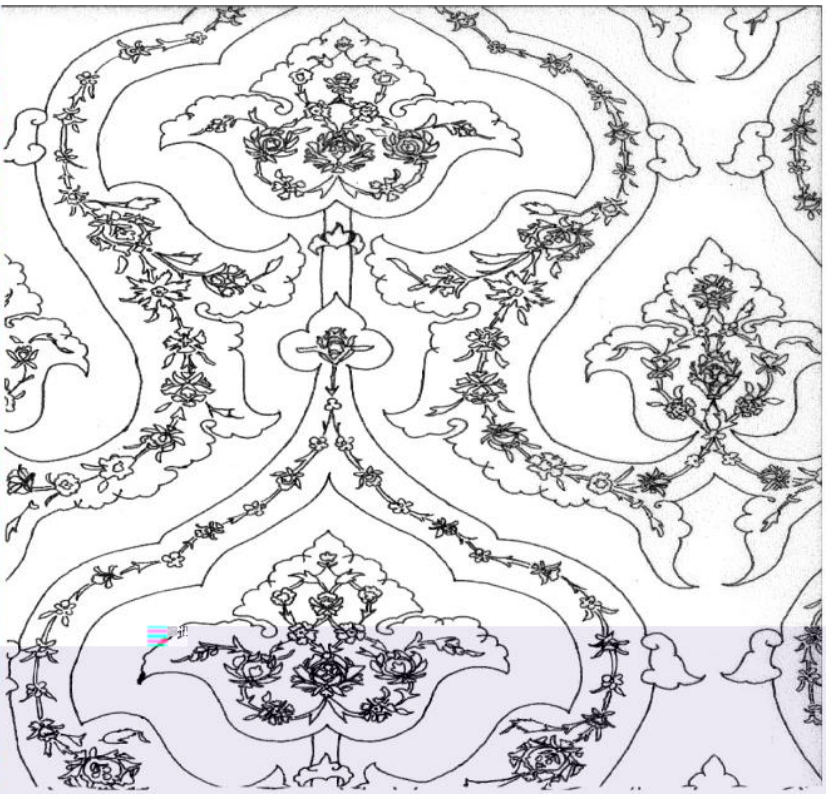

Fig. 6.(a) Kemha Fabric with Palmet and RumilMotif(Atasoy, 2001); (b)Drawing of Kemha Fabric with Palmet and Rumil Motif

It is dated to the first half of the sixteenth century. It has been used as short-sleeved caftan. Hataies and mine flowers filled the inside of the fabric that was formed on to the red surface with palmet and rumils. Pattern placement has been made in horizontal layout. The caftan that was made of Kemha fabric is available in Topkapı Palace museum as the number of $13 / 46$.

a

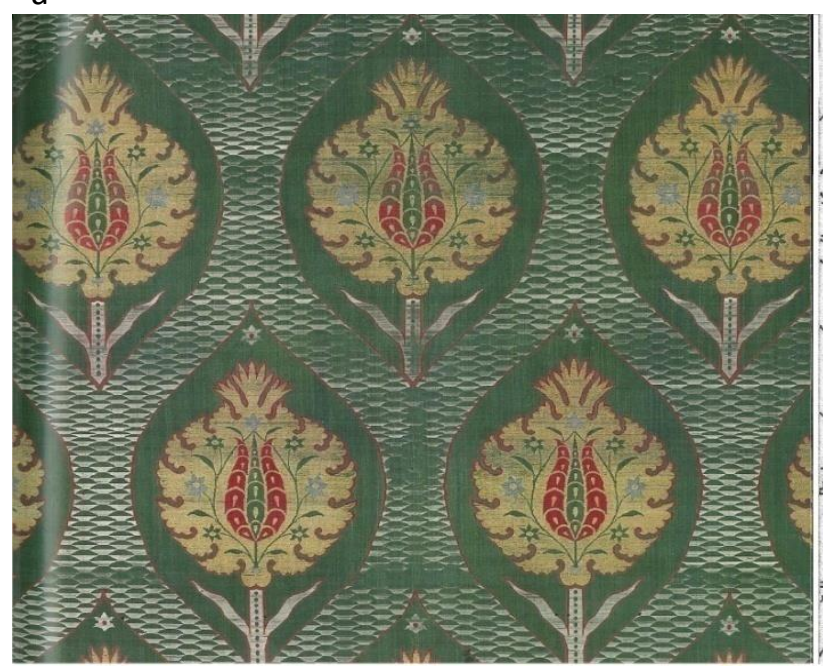

b

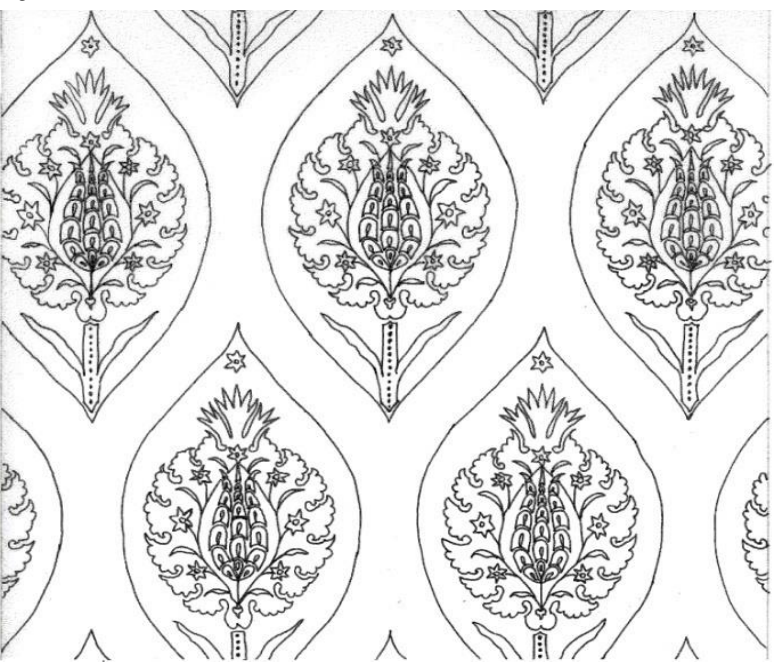

Fig. 7. (a)Green Kemha Fabric ( Bilgi, 2007); (b)Drawing of Green Kemha Fabric 
It is dated to the second half of sixteenth century. The inside of oval medallions that opens one by one to another on to green surface looks like stylized pomegranate. The tulip motif, mine flowers, branch and leaves can be seen in the middle of stylized pomegranate. While it has been seen tulip handle and leaves under the stylized pomegranate, One mine flower filled the inside of the medallion. Green, gold colour, blue, cream colour have been used in fabric. Fabric pattern layout is in staggered sheme, kemha fabric is available in Lady Sadberk Museum as the number of 176.25-D.262.

a

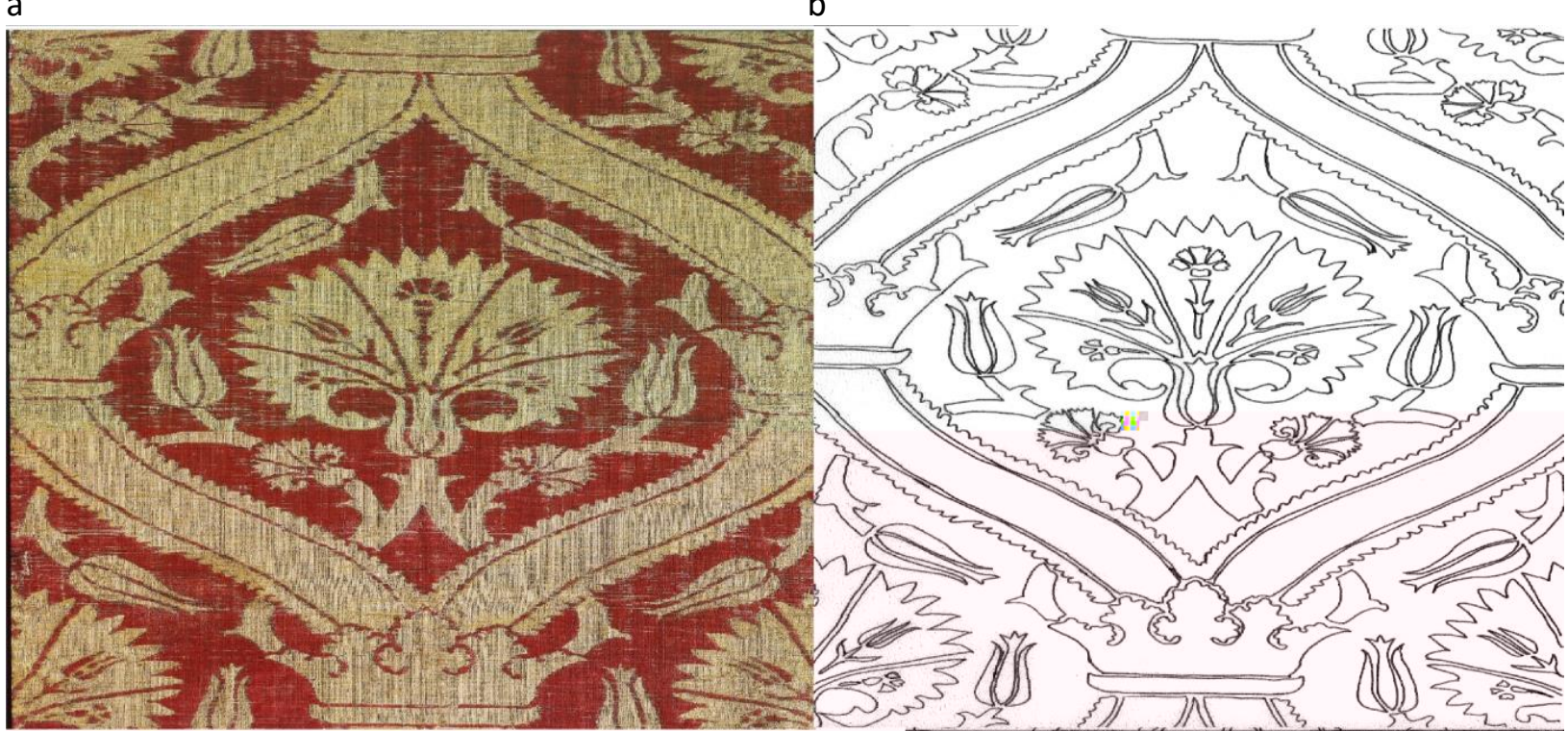

Fig. 8.(a)Çatma Fabric with Patterned Cloves (Bilgi, 2007); (b)Drawing of Çatma Fabric with Patterned

Cloves

It is dated to the second half of seventeenth century. The leaves of cloves with five dividing parts on to the red surface rise from the tulip motif. Five divided parts stylized cloves come to the middle of medallion. The inside of clove has handle and fills with cloves inside as a whole. Two cloves bottom, tulips at the top surround the side of cloves. Crown motif has been seen on the medallion. Fabric pattern placement process is staggered. Red and cream colours have been used. Brocade fabric is available in Lady Sadberk museum as the number of 12189-D.177.

a b

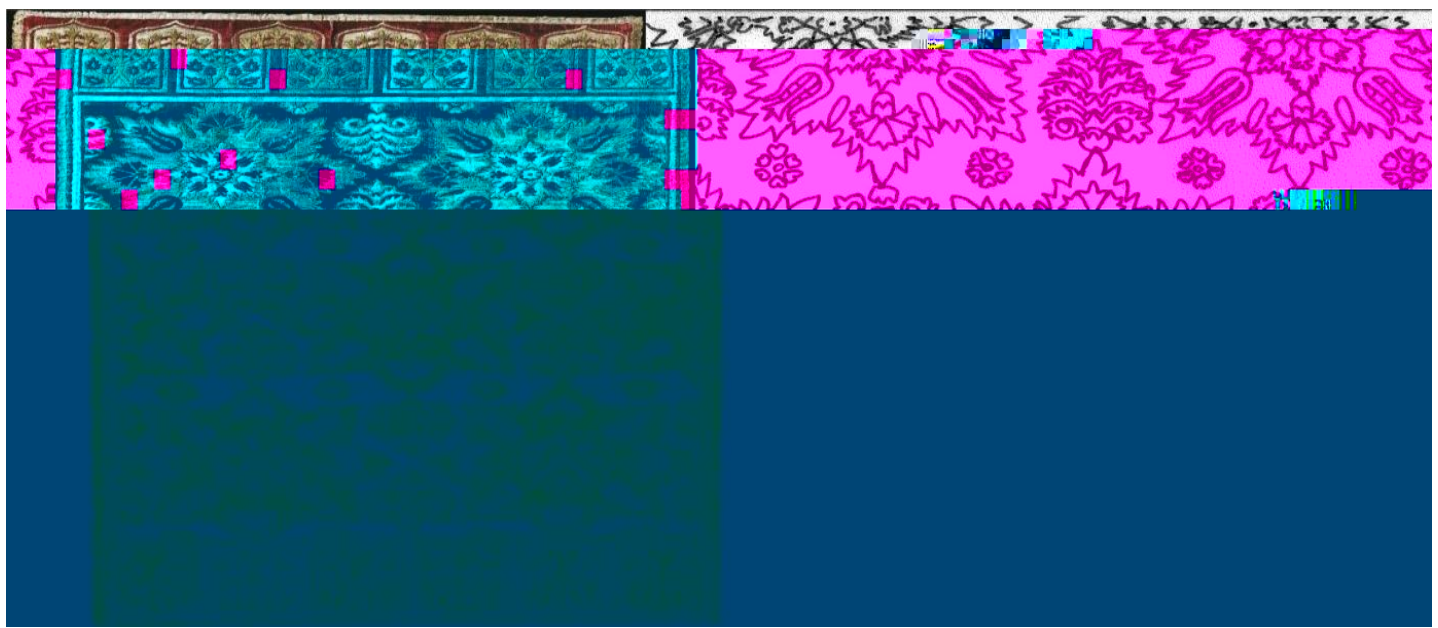

Fig 9.(a) ÇatmaFabric with Star Motif as Eight Sleeves ( Bilgi, 2007); (b)Drawing of Çatma Fabric with Star Motif as Eight Sleeves 
Ozkan, N. (2016). An overview of classical ottoman art of fabric, Global Journal on Humanites \& Social Sciences. [Online]. 03, pp 648-656. Available from: http://sproc.org/ojs/index.php/pntsbs doi: http://dx.doi.org/10.18844/gjhss.v0i0.269

It is dated to seventeenth century. The red surface of the fabric has been filled eight sleeved stars, stylized palm trees that come from the bottom and top sides. Two eight sleeved stars have been seen in the eight sleeved stars. There is a flower in the middle and there is eight sleeved star around. Tulips and hyacinths rise one by one on the top of eight sleeved star. Eight sleeved star surrounds the tulips and hyacinths. Stylized tulips and cloves have come out on the top of eight sleeved star. The third eight sleeved star surrounds the tulips and cloves as well. Stylized rose motifs have been seen in both sides of fabrics in niche. Red, green, cream colour, gold colour have been used in Çatma fabric. Staggered table has been used as pattern table. Fabric is available in Lady Sadberk Museum as the number of 14069-D.194.

\section{Results}

We owe this rich fabric collection to the old beautiful traditions. All clothes of dead Sultans are bundled, labelled and sent to Esvap Treasure and used to be protected seriously. Of course the clothes of Sultan in all his life used to be packed and protected not after his dead. Putting individual goods in dead sultans' and princes' shrines was another tradition. In the period of Republic, when the palace turned into museum, these caftans had been gathered from shrines and added to collections. So now we can know these caftans and owners (Tezcan, 1982). Thanks to caftans, dating can be done correctly and easily. So the style of fabric, motive, fabric character, technique, material can be solved easily. Besides, the pleasures of Sultans and personalities come true.

The fabrics that have been observed in research are Kemha, Çatma and Serenia. These fabrics are in silk fabric groups. The measures changes among 60-64-65 centimeters. The surface colour is usually red, green and cream in observed examples. Blue, red, green, gold colour, cream colours have been used in fabrics. There are Seal of Suleyman, carnations, tulips, roses, rosebuds, pomegranate, apple, verbena, claw, error, arabesques, palmet, coin, tiger skin patterns in sixteenth century fabrics. Carnations, tulips, hyacinth, verbena, pomegranate, palm tree, crown, medallion, eight arm star motifs are seen in seventeenth century fabrics.

Silk fabrics have been separated into five groups as pattern settled including scroll up, staggered, horizontal layout, inline layout and striped top order (Atasoy, 2001). The classical period fabrics in research are staggered layout, scroll up order and horizontal order pattern tables. The idea of infinity is essential in Turkish fabrics. In all fabrics, the motifs can be weaved forever. Fabrics are weaved according the needs, for sacred places it is written, for clothes it is floral motif and figure. According their using weaved forever and sewed side by side, the endless motifs have been used for home textiles of course by limited bottom, sides, tops. While sixteenth and seventeenth century fabric art was having the brightest time, it entered standstill period after the second half of seventeenth century.

The decline beginning with Tulip Period in eighteenth century, it showed itself in fabric art as showed in other arts. It means that the decline has been seen in fabric art. Since the State had economical trouble, the using wires with silver and gold have been banned in eighteenth century (Salman, 1998). After this century, the Western influence has seen itself in motifs as well. The special fabrics haven't been weaved like classical period fabrics after this period. The classical period fabrics that come to our age have placed in museums as valuable monuments. Besides, it will make us remember the glories of Ottoman and let the future generations know about them. 
Ozkan, N. (2016). An overview of classical ottoman art of fabric, Global Journal on Humanites \& Social Sciences. [Online]. 03, pp 648-656. Available from: http://sproc.org/ojs/index.php/pntsbs doi: http://dx.doi.org/10.18844/gjhss.v0i0.269

\section{References}

Atasoy, Nurhan, Walter B. Denny, Louise W. Mackie, (2001). HülyaTezcan, Silk, Londra Bakırcı, N. (2012). Konya Museum of the Convent of the Palace Fabric Catalogue, Konya Bilgi, H. (2007). Çatma Ottoman Silk Weaving and Kemha, İstanbul Dinçol, A. (1982). Encyclopedia of Anatolian Civilizations 5 Visual Publications, EsinerÖzen, M. (1980). Turkish Cloth Names, i.Ü.E.F. History Magazine, Number: 32, i̇stanbul Küçükerman, Ö. (2007). Industry and Design Race Two in One Empire Topkapi and Dolmabahce Palace, i̇stanbul Nutku, Ö. (1985). Seventeenth Century Palace of Fabrics, History and Society, Issue: 22

Önder, M. (1993). Today The Turkish Art From The Beginning, Ankara

Öz, T. (1946). Turkish Fabrics And Velvet Are, ìstanbul

Salman, F. (1998). Understanding the History of Turkish Fabric Patterns and Colors, Ataturk University Journal of the Institute of Fine Arts, Issue: 4, Erzurum

Sezgin, Şerife, Önlü Nesrin, (1994). Classical Ottoman Palace Silk Fabrics, Textile and Engineers, Volume 8, Issue 43-44

Süslü, Ö., (1976). Topkapi Palace and the Turkish and Islamic Arts Museum XVI Found Investigation of the Fabric of Ottoman Miniature Century Pattern, Art History Yearbook VI, İstanbul.

Süslü, Ö., (1973). Fabric Patterns in the sixteenth century Ottoman miniature Istanbul University Library in the museum An Essay on "i.Ü.EF Art History Yearbook V,ístanbul

Tezcan, H. (1993). Atlaslar Atlası, İstanbul

Tezcan, H. (1982). Caftans of the Sultans Fabrics Carpets, Art 7 Topkapi Palace Museum, istanbul

Tezcan, H. (1984). Examples From Turkish Fabric, Our Art World, Year: 10, Issue:31, İstanbul

Uğurlu, A. (1994). Ornamental and Grandeur of the Ottoman Fabric, Interest, Issue:76, i̇stanbul

Ülgen, A. (1996). Traditional Arts in the Ottoman Empire, The Ottoman Cultural History Culture Encyclopedia, Volume: 3, istanbul

Yatman, N. (1945). Turkish Fabrics, Ankara

Züber, H. (1972). Turkish Decorative Arts, Ankara 